\title{
Antiviral effect of baicalin on Marek's disease virus in CEF cells
}

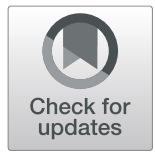

Fan Yang ${ }^{1,2,3}$, Chun Feng ${ }^{1,2,3}$, Yongxiu Yao ${ }^{4}$, Aijian Qin ${ }^{1,2,3}$, Hongxia Shao ${ }^{1,2,3}$ and Kun Qian ${ }^{1,2,3,5,6^{*}}$ (D)

\begin{abstract}
Background: Baicalin, the main metabolic component of Scutellaria baicalensis Georgi, has various pharmacological properties including anti-inflammatory, anti-oxidant, anti-apoptotic, anti-bactericidal and anti-viral. The purpose of this study was to investigate the anti-Marek's disease virus (MDV) activities of baicalin in CEF cells.

Results: Here, we showed that baicalin could inhibit viral mRNA, protein levels and overall plaque formation in a time-dependent manner. We also found that baicalin could consistently inhibit MDV replication and directly affect the virus infectivity. Moreover, baicalin treatment has no effect on expression level of antiviral cytokine and inflammatory cytokines in MDV infected CEFs.
\end{abstract}

Conclusions: These results demonstrate that baicalin could be a potential drug against MDV infection.

Keywords: Marek's disease virus, Baicalin, Antiviral activity, Inhibition

\section{Background}

Marek's disease virus (MDV) is a member of alpha-herpes virus subfamily, and serotype 1 strains are the etiologic agentof Marek's disease (MD), which is a highly contagious and infectious malignant lymphoid neoplastic disease. MD is a neoplastic disease of chickens and other gallinaceous birds. It is one of the major diseases that threatens poultry industry worldwide and causes heavy economic losses [1]. Current report showed that half of the world countries had case reports of MDV infection [2]. In recent years, many reports of the onset of MDV have also been declared in vaccinated chickens [3-6]. The virulence of MDV has been continuously evolved and gradually increased under the pressure of vaccination. In MD vaccine can prevent tumorigenesis and immunosuppression, but the virus can still replicate into fully infectious virus particles and shed cell free mature

\footnotetext{
* Correspondence: qiankun@yzu.edu.cn

${ }^{1}$ Ministry of Education Key Lab for Avian Preventive Medicine, Yangzhou University, No.48 East Wenhui Road, Yangzhou, Jiangsu 225009, P.R. China ${ }^{2}$ Jiangsu Key Lab of Preventive Veterinary Medicine, Yangzhou University, No.48 East Wenhui Road, Yangzhou, Jiangsu 225009, P.R. China

Full list of author information is available at the end of the article
}

virions through skin dander and dust. Thus, the ideal MDV vaccine would be capable of controlling the replication of MDV in chickens and stopping the shedding of virions [2].

Traditional Chinese Medicine (TCM) has been widely used to treat and prevent illnesses for thousands of years. Baicalin, a flavonoid compound, is the main effective component of Scutellaria baicalensis Georgi which is one of the commonly used herbal medicine in China [7]. Previous studies have reported that baicalin exibited inhibitory effects against Herpes simplex virus 1 (HSV-1) [8]. It could inactivate free Dengue virus (DENV) particles and interfere with intracellular viral replication by affecting the attachment of DENV to host cells [9]. As a neuraminidase (NA) inhibitor, it had anti-influenza A virus infection activity [10]. It could also directly kill Newcastle disease virus (NDV) and block intracellular NDV replication. In our previous report, we showed that baicalin had antiviral effect on avian leukosis virus subgroup J through targeting virus internalization [11]. However, the inhibitory effects of baicalin on MDV infected CEF cells were not evaluated. Therefore, the present study focused on the antiviral properties of 
baicalin and its mechanism against MDV replication in CEFs.

\section{Results \\ Cytotoxicity of baicalin on CEF cells}

In order to exclude the possibility that the antiviral activity was due to cytotoxicity of the chemical, a CCK-8 cytotoxicity assay was performed. After treatment with baicalin at concentrations of 5,10 and $20 \mu \mathrm{g} / \mathrm{mL}$, the relative cell viability was above $90 \%$, whereas the viability was under $50 \%$ after treatment with baicalin at the concentrations of $40 \mu \mathrm{g} / \mathrm{mL}$ (Fig. 1) No difference in cell morphology was observed at a concentration of $\leq 20 \mu \mathrm{g} /$ $\mathrm{mL}$. Thus, baicalin was used at a concentration of no more than $20 \mu \mathrm{g} / \mathrm{mL}$ in the subsequent experiments.

\section{Antiviral activity of baicalin on replication of MDV in CEF cells}

After $96 \mathrm{~h}$ of inoculation, it was found that the transcription levels of the Meq and gB genes were significantly decreased at concentration of $20 \mu \mathrm{g} / \mathrm{mL}$ compared with the control group (Fig. 2a). The results of viral plaque counting, indirect immunofluorescence staining, and Western blot analysis also showed that baicalin at $20 \mu \mathrm{g} /$ $\mathrm{mL}$ significantly inhibited viral protein expression and plaque formation (Fig. 2 B-D). In contrast, the $2 \mu \mathrm{g} / \mathrm{mL}$ low-dosage group did not show any significant inhibitory effect. These results indicate that $20 \mu \mathrm{g} / \mathrm{mL}$ baicalin has significant antiviral activity against MDV RB-1B infection in CEF cells.

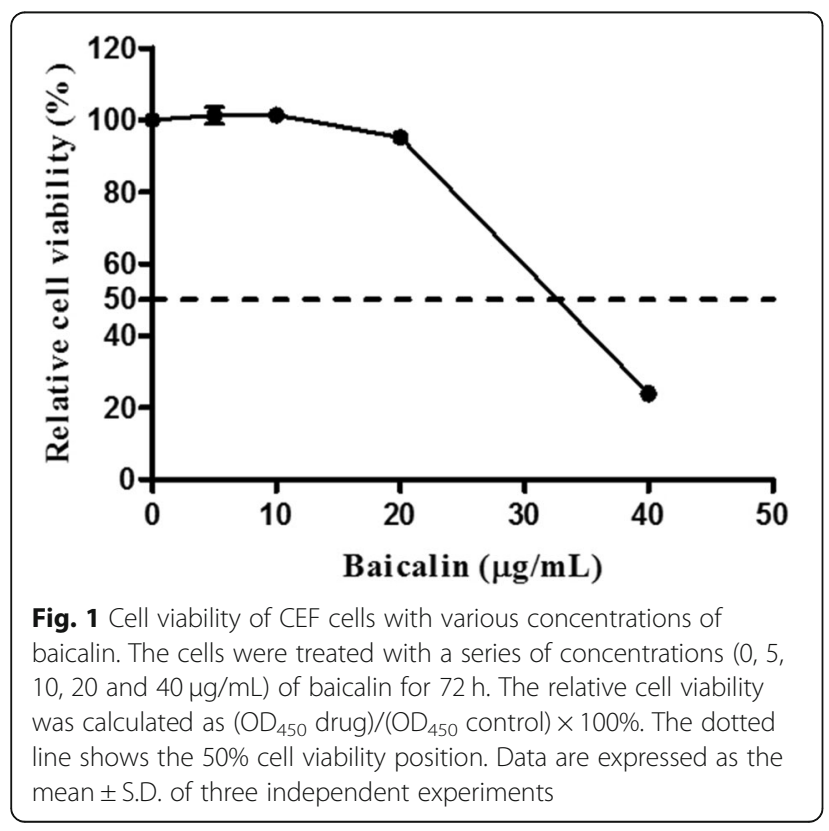

Time-dependent manner of baicalin inhibition on MDV replication

Virus-infected CEF cells were harvested at 24, 48, 72, 96, and $120 \mathrm{~h}$ after viral infection for plaque counting, realtime PCR and indirect immunofluorescence assay. The viral gene expression was continuously inhibited at different time points after treatment with baicalin at $20 \mu \mathrm{g} / \mathrm{mL}$. Significant differences were observed from D1 to D5 postinfection as shown in Fig. 3a, b, and this inhibitory effect is alleviated when viral infection level increases. Viral plaque counting and indirect immunofluorescence assay results were also consistent with real-time PCR results (Fig. $3 \mathrm{C}$ and D). Overall these results suggest that baicalin at $20 \mu \mathrm{g} / \mathrm{mL}$ had a significant inhibitory effect on MDV replication in a time-dependent manner.

\section{Inhibitory effects of baicalin depending on the time of application}

According to the experimental design, three time points of drug application were carried out. Real-time PCR and plaque counting experiments revealed that baicalin had significant inhibition on MDV replication only in the P3 protocol, which $20 \mu \mathrm{g} / \mathrm{mL}$ of baicalin was added to maintainance medium after virus adsorbing. But significant inhibition was not observed in the $\mathrm{P} 1$ and $\mathrm{P} 2$ protocol (Fig. 4 A, 4B).

In order to investigate the time points exerting the antiviral effect of baicalin on the viral intracellular replication cycle, baicalin $(20 \mu \mathrm{g} / \mathrm{mL})$ was added to CEF cells at $0,1,6,12$, and $24 \mathrm{~h}$ after virus adsorption, respectively. The results in Fig. 4c and d demonstrated that at the level of viral gene expression, the inhibitory effect weakened over time, but the persistence of viral plaque formation was significantly inhibited by baicalin.

\section{Baicalin directly affects infectivity of MDV}

The virus suspension was incubated with the drug for $1.5 \mathrm{~h}$ at $37^{\circ} \mathrm{C}$, and CEF cells were infected for $96 \mathrm{~h}$. Realtime PCR and plaque counting results showed that viral gene expression and virus replication were significantly lower in the drug-treated group compared to untreated virus suspension group (Fig. 5). This result indicates that $20 \mu \mathrm{g} / \mathrm{mL}$ baicalin can directly inhibit the infectivity of MDV.

\section{No effect of Baicalin on pro-inflammatory cytokines and IFN- $\beta$ gene expression in MDV infected CEF cells}

Anti-inflammatory effects of baicalin in vitro and in vivo have been reported before $[12,13]$. In this study, we investigated whether baicalin affected the expression of pro-inflammatory cytokines and IFN- $\beta$ in virus-infected CEF cells. The results in Fig. 6 showed that baicalin significantly reduced the mRNA levels of IFN regulatory 


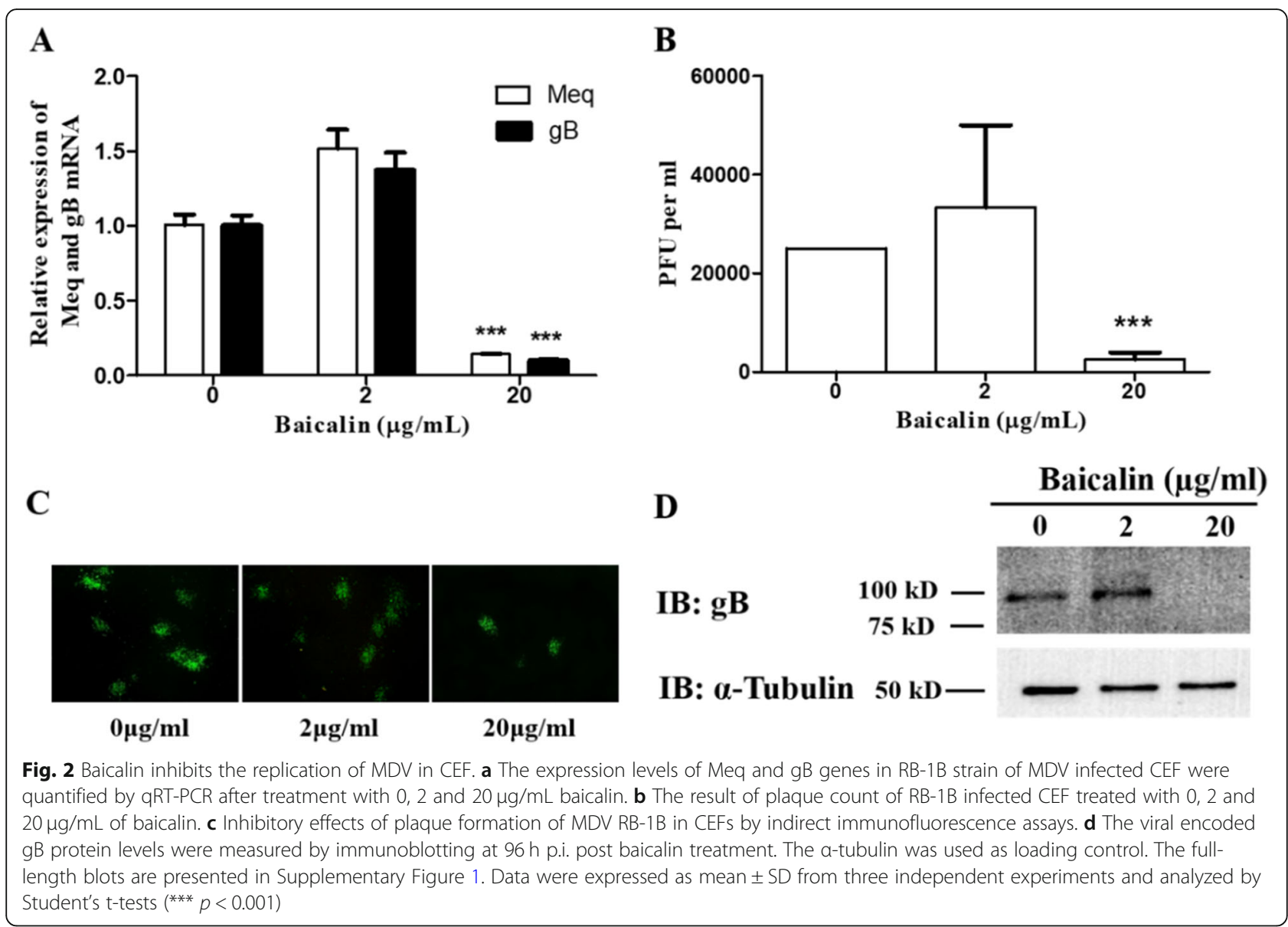

factor IRF7, whereas no significant difference was observed at the mRNA levels of IL- 6 , IL- $1 \beta$ and IFN- $\beta$.

\section{Discussion}

It is well known that MDV vaccine can provide protective immunity but not sterile immunity which means that the vaccine can inhibit the development of lymphoma but can not prevent virus replication and shedding [2]. Therefore, the development of effective antiviral drugs has positive significance for the prevention and control of MD.

In recent years, the research on antiviral property of Traditional Chinese Medicine has attracted the attention of research groups worldwide due to its minimal side effect and low toxicity [14]. The baicalin as a flavonoid is the metabolite of baicalein and the evidence of its antiviral role against $\mathrm{HSV}-1$, Herpes simplex virus 2 (HSV2), Zika virus (ZIKV), Influenza A virus (IAV), Duck hepatitis A virus type 1 (DHAV-1), and NDV has been reported [7, 8, 15-17]. In our previous study, we demonstrated that baicalin has an specific inhibitory effect on ALV-J infection by reducing the infectivity and affecting virus internalization [11]. In the current study, we showed that baicalin exhibited significant inhibitory activity against MDV infection in CEFs in a timedependent manner, with decreased viral gene and viral protein expression as well as plaque counts (Fig. 1 and Fig. 2). This is similar to the results of previous studies on antiherpetic activities of flavonoids against herpes simplex virus [8]. To explore the antiviral mechanism, the drug was added at different time points and virucidal assay were carried out. The results showed that baicalin could consistently inhibit MDV replication in the viral replication cycle when baicalin was added post infection in CEFs, while no antiviral effect was observed in the pre-treatment and virus absorption steps (Fig. 4). In addition, the plaque formation and yield were reduced significantly in virucidal assay (Fig. 5), which was consistent with previous reports that other chemical compounds extracted from Chinese medicinal herbs such as dipotassium glycyrrhizinate and sodium tanshinone IIA sulfonate could directly inactivate MDV particles also [18]. This result suggests that different TCM from different chemical family may share the same antiviral mechanism. Published study has shown that baicalin can inhibit the NDV infection by blocking HN binding to sialic acid-containing receptors and virus adsorption [15], however we do not know how baicalin affects the spread 
$\mathbf{A}$

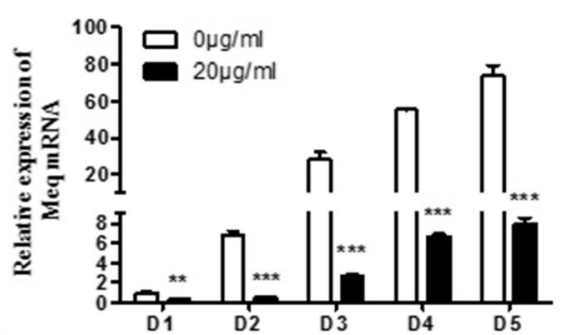

B

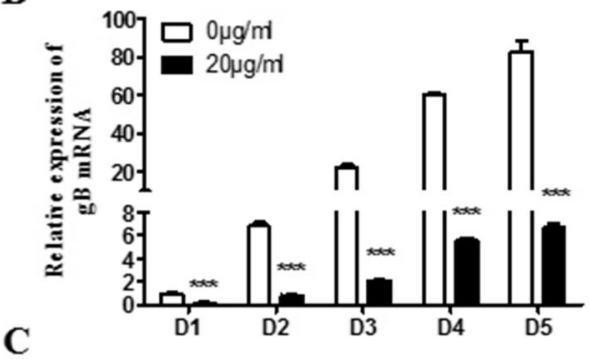

C

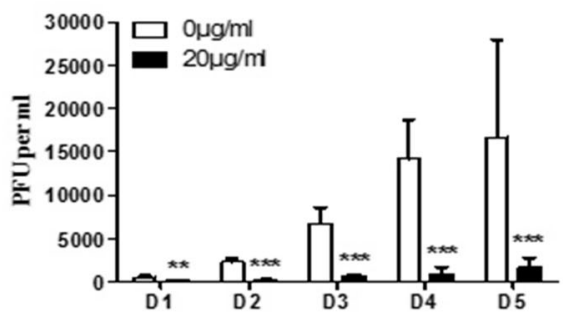

D

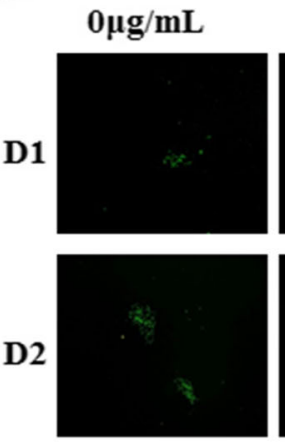

$20 \mu \mathrm{g} / \mathrm{mL}$
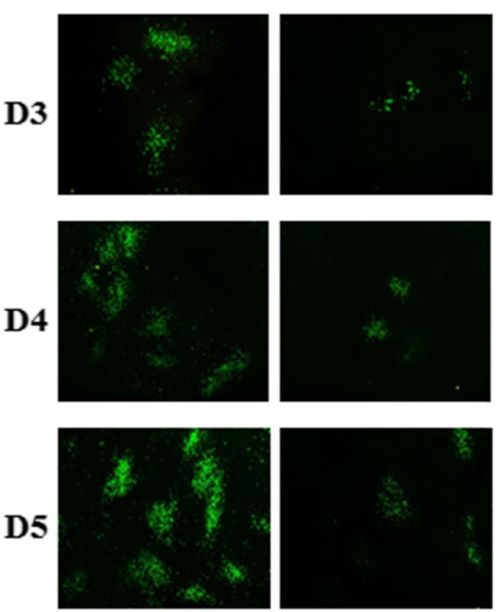

Fig. 3 Time-dependent manner of baicalin inhibition on MDV replication in CEF. Total cellular RNA was extracted from day 1 to day 5 p.i., and the expression levels of Meq gene (a) and gB gene (b) were detected by qRT-PCR. $\mathbf{c}$ The results of plaque count of the MDV RB-1B strain infected CEF treated with 0 and $20 \mu \mathrm{g} / \mathrm{mL}$ of baicalin at different time points. $\mathbf{d}$ Direct observation of viral plaque formation dynamics by indirect immunofluorescence assays from day 1 to day 5 post virus infection. Data were expressed as mean \pm SD is for A, B and C only from three independent experiments and analyzed by Student's t-tests $\left(^{* *} p<0.01,{ }^{* * *} p<0.001\right)$

of MDV from cell to cell yet as the mechanism of how MDV enters the host cells is not fully understood.

In MDV infected CEF cells, the expression level of IFN regulatory factor 7 (IRF7) increased obviously [19]. After baicalin treatment, the IRF7 expression decreased significantly, which was synchronized with viral replication reduction. It is well known that IRF7 is an important transcription factor of interferon. However, the expression of IFN- $\beta$ did not change despite of the significant down-regulation of IRF7 with baicalin treatment in this study (Fig. 6b), suggesting that the expression of IFN- $\beta$ caused by MDV infection is regulated by other transcription factors. In addition, the expression levels of pro-inflammatory factors IL-1 $\beta$ and IL-6 were slightly decreased in MDV infected CEF cells treated with baicalin, but the difference was not significant. This is inconsistent with previous study that baicalin controls influenza A virus infection by down-regulating the RIGI-like receptors signaling pathway [20]. This difference may be related to the different antiviral mechanisms of baicalin in different cells.

\section{Conclusions}

In conclusion, baicalin displayed strong anti-MDV effect in a time dependent manner. Furthermore, baicalin reduces MDV replication after viral adsorption and affects the virus infectivity when MDV was pre-incubated with baicalin before infecting CEFs. Moreover, baicalin reduced the expression level of IRF7, but had no effect on expression of inflammatory cytokines in virus infected CEFs. Taken together, these results suggest that baicalin has potential to be further developed as anti-MDV drugs for use in clinic. Future studies will explore the in vivo antiviral effects of baicalin in chickens.

\section{Methods}

Virus, cells and reagents

The RB-1B strain of MDV is cell-associated virus, and it was stored in our laboratory in liquid nitrogen. Chicken embryo fibroblast (CEF) cells were prepared from 9 days old SPF chicken embryo. The SPF chicken embryos were obtained from the Merial Vital Laboratory Animal Technology Co., Ltd. (Beijing, China), and the animal 
A

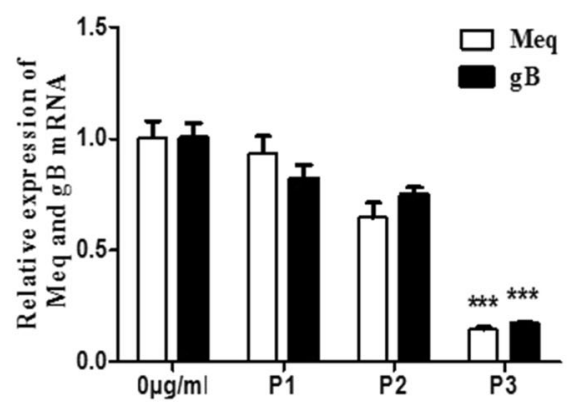

C

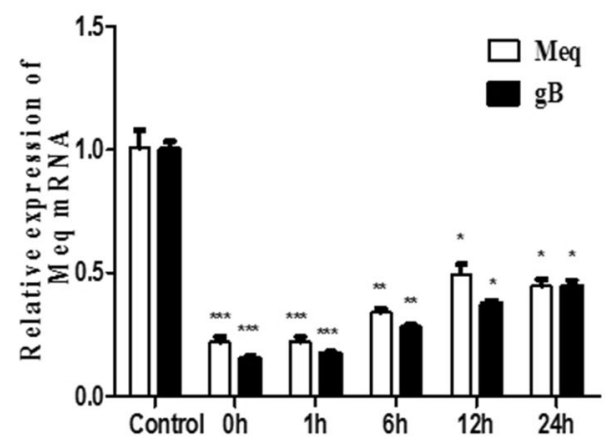

B

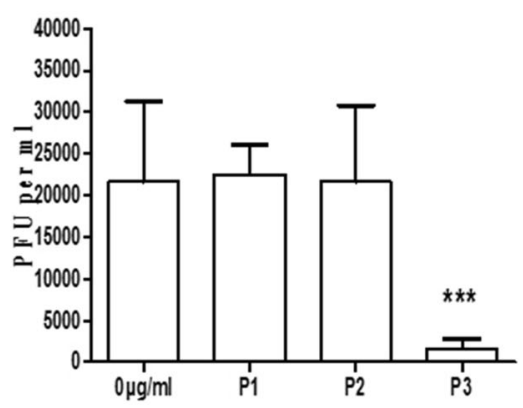

D

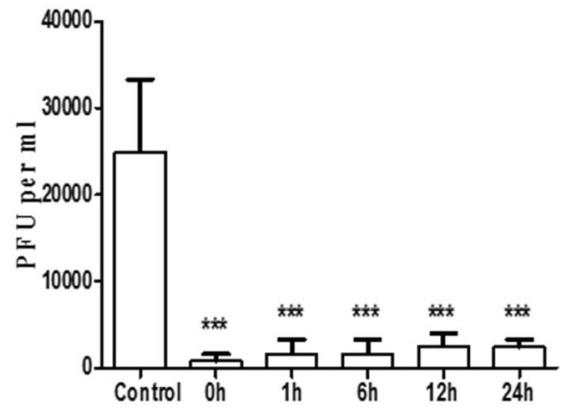

Fig. 4 Effects of baicalin on MDV RB-1B replication are dependent on the time of baicalin application. a The gene expression level of Meq gene and $\mathrm{gB}$ gene were detected by qRT-PCR $\mathbf{b}$ Viral quantity was detected by plaque counting. $0 \mu \mathrm{g} / \mathrm{mL}$ indicates no baicalin treatment, P1 indicates pretreatment with $20 \mu \mathrm{g} / \mathrm{mL}$ baicalin for $2 \mathrm{~h}$ before virus adsorption, P2 indicates $20 \mu \mathrm{g} / \mathrm{mL}$ baicalin and the virus were added at the same time, and P3 indicates $20 \mu \mathrm{g} / \mathrm{mL}$ baicalin was added after virus adsorption. (C+D) $20 \mu \mathrm{g} / \mathrm{mL}$ baicalin was added at $0,1,6,12$, and $24 \mathrm{~h}$ after virus adsorption, and the virus was harvested $96 \mathrm{~h}$ post infection for detection of Meq and gB expression by qRT-PCR (c), and virus quantification by plaque counting (d). Data were expressed as mean \pm SD from three independent experiments and analyzed by Student's t-tests $\left(^{*} p<0.05,{ }^{* *} p<\right.$ $\left.0.01,{ }^{* * *} p<0.001\right)$

experiments were performed according to the institutional animal care guidelines and approved by the Animal Care Committee of College of Veterinary Medicine, Yangzhou University. The fully confluent monolayers of CEF cells were grown in Dulbecco's modified Eagle medium (DMEM; GIBCO, Shanghai China) supplemented with $5 \%$ fetal bovine serum (FBS), $100 \mathrm{U} / \mathrm{mL}$ of penicillin, and $100 \mathrm{~g} / \mathrm{mL}$ of streptomycin at $37^{\circ} \mathrm{C}$ in a $5 \% \mathrm{CO}_{2}$ atmosphere. Baicalin was purchased from SIGMA (Shanghai, China) and diluted in dimethyl sulphoxide (DMSO). The specific monoclonal antibody against MDV gB protein, BA4, was generated in our laboratory. And the anti-tubulin monoclonal antibody was purchased from SIGMA (Shanghai, China).

\section{Cytotoxicity test}

The cytotoxicity of baicalin on CEF cells was determined using a cell counting kit, CCK-8 kit (Beyotime, Shanghai, China). Briefly, $4.0 \times 10^{4} /$ well CEF cells were seeded in 96-well plates, and $150 \mu \mathrm{L}$ of baicalin at $0,5,10,20$ and $40 \mu \mathrm{g} / \mathrm{mL}$ in DMEM maintenance medium was added to each well. After incubating for $72 \mathrm{~h}$ in a $37^{\circ} \mathrm{C}$ incubator,
CCK-8 solution $(15 \mu \mathrm{L})$ was added to each well. Incubation was continued for $1 \mathrm{~h}$ and the absorbance at 450 $\mathrm{nm}$ was measured. The relative cell viability rate was determined as a percentage for each concentration as $\left(\mathrm{OD}_{450}\right.$ drug $) /\left(\mathrm{OD}_{450}\right.$ control $) \times 100$.

\section{Virus infection and chemical treatment}

To investigate the inhibitory effect of baicalin on MDV replication, CEF cells were seeded in 12-well plates $\left(6.0 \times 10^{5}\right.$ cells/well $)$ and pretreated for $2 \mathrm{~h}$ at $37^{\circ} \mathrm{C}$ with DMEM maintenance medium containing $0.5 \%$ serum and 0,2 or $20 \mu \mathrm{g} / \mathrm{mL}$ baicalin. The cells were then infected with $200 \mathrm{PFU}$ of MDV and incubated under the exposure of the drug for $96 \mathrm{~h}$ before harvesting. The collected cells were used for plaque counting, real-time PCR, western blotting and indirect immunofluorescence assay.

To determine the dynamics of baicalin inhibition of viral replication, CEF cells in 12 well plates were pretreated with $20 \mu \mathrm{g} / \mathrm{mL}$ baicalin for $2 \mathrm{~h}$, and then 200 PFU of MDV per well was inoculated. After $4 \mathrm{~h}$ of virus adsorption, the medium was replaced by $20 \mu \mathrm{g} / \mathrm{mL}$ 


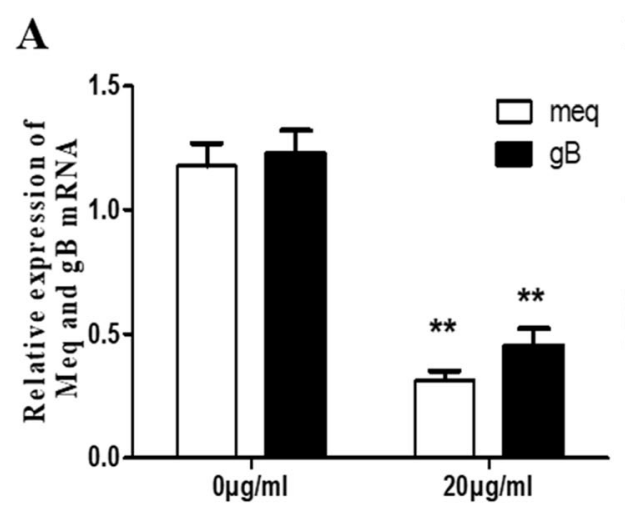

\section{B}

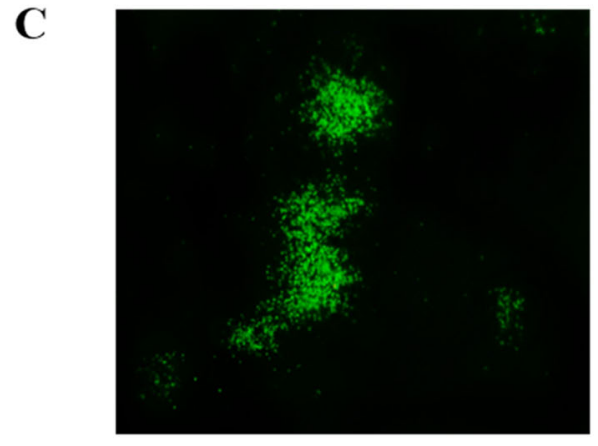

$\mathbf{0 \mu g} / \mathbf{m l}$
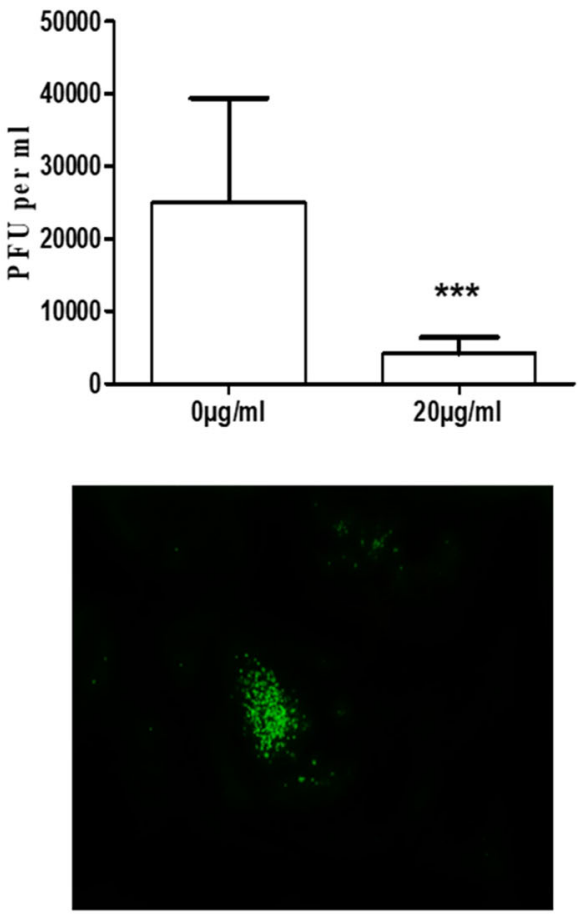

$20 \mu \mathrm{g} / \mathrm{ml}$

Fig. 5 Direct virucidal activity of baicalin on MDV. Compounds were mixed with MDV at 0 and $20 \mu \mathrm{g} / \mathrm{mL}$ respectively and incubated in a $37^{\circ} \mathrm{C}$ incubator for $1.5 \mathrm{~h}$, then inoculated onto CEF until harvest. The RNA of the cells were extracted for qRT-PCR to detect the expression level of the Meq gene and the gB gene (a). The virus quantity was detected by plaque counting (b). The indirect immunofluorescence assay showed the similar results with plaque counting (c). Data were expressed as mean \pm SD from three independent experiments and analyzed by Student's ttests $\left.{ }^{* *} p<0.01,{ }^{* * *} p<0.001\right)$

baicalin diluted in DMEM maintenance solution with $0.5 \%$ serum. Virus infected cells were harvested at 1,2 , 3,4 and 5 days respectively for plaque counting, realtime PCR detection and indirect immunofluorescence assay.

\section{Different models of drug treatment and virus infection}

In order to investigate the mechanism of viral inhibition by baicalin, a time-of-drug addition experiment was carried out as described previously with minor modifications [11]. Briefly, in the first protocol (P1), CEF cells were pre-treated with $20 \mu \mathrm{g} / \mathrm{mL}$ baicalin for $2 \mathrm{~h}$ at $37^{\circ} \mathrm{C}$ before viral adsorption. After removing the culture medium containing the drug, the cells were inoculated with $200 \mathrm{pfu}$ virus and incubated with the maintainance medium containing $0.5 \% \mathrm{FBS}$ at $37^{\circ} \mathrm{C}$ in an atmosphere of $5 \% \mathrm{CO}_{2}$ until harvest; in the second protocol (P2), a mixture of $200 \mathrm{PFU}$ virus suspension and $20 \mu \mathrm{g} / \mathrm{mL}$ of baicalin were added to cell monolayers and incubated for $2 \mathrm{~h}$ at $37^{\circ} \mathrm{C}$. After removing the medium, the cells were incubated with maintainance medium at $37^{\circ} \mathrm{C}$ in an atmosphere of $5 \% \mathrm{CO}_{2}$; in the third protocol (P3),
$20 \mu \mathrm{g} / \mathrm{mL}$ of baicalin was added to maintainance medium after virus adsorbing for $4 \mathrm{~h}$ in a $37^{\circ} \mathrm{C}$ incubator. After $96 \mathrm{~h}$ of incubation, viral gene expression and plaque formation were examined for all protocols. In order to understand the correlation between baicalin and virus infection, the time course analysis was performed. CEF cells were infected with 200 PFU MDV for viral adsorption. Baicalin $(20 \mu \mathrm{g} / \mathrm{mL})$ was then added into the cells at $0 \mathrm{~h}, 1 \mathrm{~h}, 6 \mathrm{~h}, 12 \mathrm{~h}$, and $24 \mathrm{~h}$ after virus adsorption, respectively. At $96 \mathrm{~h}$ post infection (p.i.), cells were haversted for viral gene expression and plaque formation.

\section{Virucidal assay}

Two hundred pfu virus were mixed with $20 \mu \mathrm{g} / \mathrm{mL}$ of baicalin and incubated at $37^{\circ} \mathrm{C}$ for $1.5 \mathrm{~h}$. After centrifugation to remove the supernatant, the virus-infected cells were resuspended and added to CEF in a 12-well plate. The inoculum was replaced with fresh $0.5 \%$ serum containing maintenance medium after $4 \mathrm{~h}$ of virus adsorption. The cells were harvested after $96 \mathrm{~h}$ post infection for plaque counting and real-time PCR. 


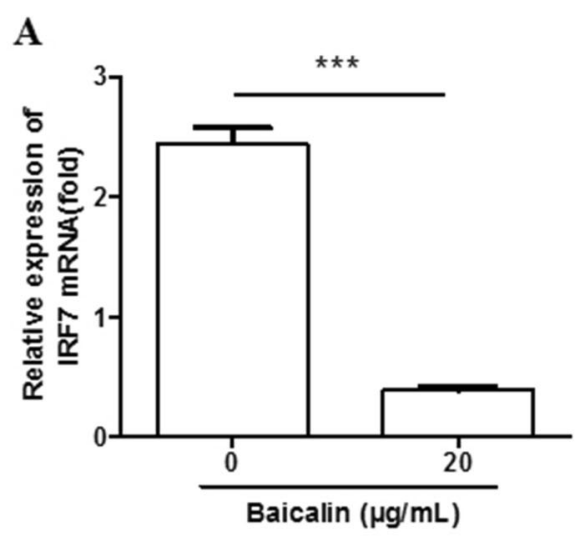

B

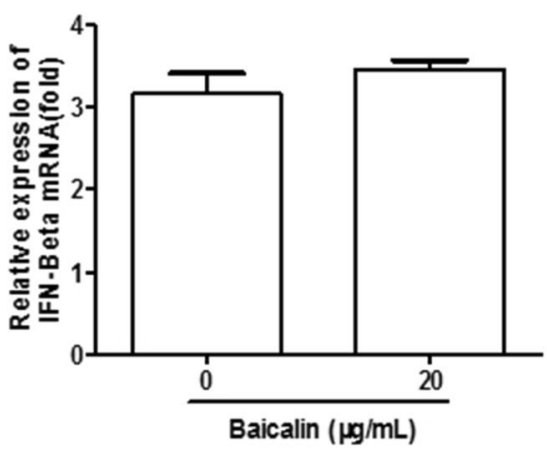

C

D
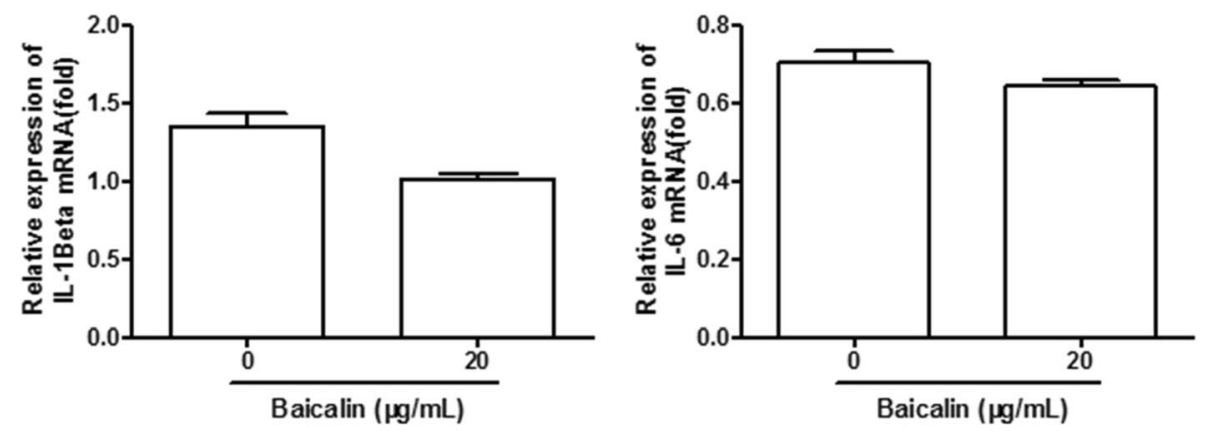

Fig. 6 The effect of baicalin on the expression of IFN regulatory factor and cytokines. a The expression of IFN regulatory factor IRF7 after baicalin treatment and MDV infection. $\mathbf{b}$ The expression of IFN- $\beta$ after baicalin treatment and MDV infection. The expression of proinflammatory cytokines IL-1 $\beta$ (c) and IL-6 (d) after baicalin treatment and MDV infection. Data were expressed as mean \pm SD from three independent experiments and analyzed by Student's t-tests $(* * * 00.001)$

\section{Plaque counting}

Virus infected CEF cells in 12-well plate were digested with $400 \mu \mathrm{L} 0.05 \%$ trypsin per well. $100 \mu \mathrm{L}$ per well of 10 fold serial diluted cells were added into 96-well CEF cells with 12 replicates of each dilution The cells were incubated at $37^{\circ} \mathrm{C}$ in an atmosphere of $5 \% \mathrm{CO}_{2}$. The number of viral plaques was counted after $96 \mathrm{~h}$. The highest dilution which has plaques in all 12 wells was used for titer calculation. The formula used is $\mathrm{PFU} / \mathrm{mL}=$ (total plaques/12) $\times 10 \times$ dilution factor.

Table 1 Primers used for real-time PCR

\begin{tabular}{|c|c|c|c|}
\hline Target gene & Sequence & Product size & Accession number \\
\hline Meq & $\begin{array}{l}\text { F 5'-GTCCCCCCTCGATCTTTCTC-3' } \\
\text { R 5'-CGTCTGCTTCCTGCGTCTTC-3' }\end{array}$ & 184 & NC-002229.3 \\
\hline gB & $\begin{array}{l}\text { F 5'-ACCCCATTCGGTGGCTTTTC-3' } \\
\text { R 5'-GCGTCCAGTTGTCTGAGG-3' }\end{array}$ & 122 & NC-002229.3 \\
\hline \multirow[t]{2}{*}{ IRF7 } & F 5'-CGTATCTTCCGCATCCCTTGG-3' & 206 & NM-205372.1 \\
\hline & R 5'-TCGTCGTTGCACTTGGAGCG-3' & & \\
\hline IFN- $\beta$ & $\begin{array}{l}\text { F 5'-GCTCTCACCACCACCTTCTC-3' } \\
\text { R 5'-GCTTGCTTCTTGTCCTTGCT-3' }\end{array}$ & 151 & NM-001024836.1 \\
\hline $\mid L-1 \beta$ & $\begin{array}{l}\text { F 5'-TAGATGTCGTGTGTGATGAG-3' } \\
\text { R 5'-GTAGAAGATGAAGCGGGTC-3' }\end{array}$ & 105 & NM-204524.1 \\
\hline IL-6 & $\begin{array}{l}\text { F 5'-CAGGACGAGATGTGCAAGAA-3' } \\
\text { R 5'-TAGCACAGAGACTCGACGTT-3' }\end{array}$ & 233 & NM-204628.1 \\
\hline \multirow[t]{2}{*}{$18 \mathrm{~S}$} & F 5'-TCAGATACCGTCGTAGTTCC-3' & 154 & AF173612 \\
\hline & R 5'-TTCCGTCAATTCCTTTAAGTT-3' & & \\
\hline
\end{tabular}




\section{Quantitative reverse transcriptase polymerase chain reaction}

The expression levels of the viral genes and cytokines were determined with real-time PCR (7500 Real-Time PCR System, ABI) as previously reported [21]. The sequences of the primers are provided in Table 1, and these primers were synthesized by Gene Script Company (Nanjing, China).

Total RNA from CEF cells was prepared using the AxyPrep Multisource Total RNA Miniprep Kit (AXYGEN, USA). $1 \mu \mathrm{g}$ of RNA was reverse transcribed into cDNA using PrimeScript RT Master Mix (TaKaRa, USA). The expression levels of viral genes were determined by real-time SYBR green quantitative PCR (7500 Real-Time PCR System, ABI). The diluted cDNA $(1 \mu \mathrm{L})$, $400 \mathrm{nM}$ primer and $10 \mu \mathrm{L}$ of SYBR Green Master Mix were used for real-time PCR in a total volume of $20 \mu \mathrm{L}$ reaction. The amplification conditions were as follows: $95^{\circ} \mathrm{C}$ for $30 \mathrm{~s}$, then 40 cycles, $95^{\circ} \mathrm{C}$ for $5 \mathrm{~s}$ and $60^{\circ} \mathrm{C}$ for $34 \mathrm{~s}$. A dissociation curve was generated to analyze each PCR product after 40 cycles. The analysis of relative gene expression data was performed using the $2^{-\Delta \Delta C T}$ method with the chicken $18 \mathrm{~S}$ as the internal reference gene.

\section{Indirect immunofluorescence}

The infected cells were fixed with acetone ethanol (3:2) for $7 \mathrm{~min}$ at room temperature. After washing three times with PBS, the fixed cells were incubated with antigB mAb BA4 $(5 \mu \mathrm{g} / \mathrm{mL})$ in PBS for $60 \mathrm{~min}$ at $37^{\circ} \mathrm{C}$, then washed with PBS followed by incubation with goat antimouse IgG conjugated with FITC (Sigma, USA) at room temperature for an additional $30 \mathrm{~min}$. The pictures were captured with a OLYMPUS fluorescence microscope.

\section{Western blot analysis}

Similar to our previous report [11], after cell lysing with RIPA buffer, the protein concentration was determined using a BCA Protein Assay Kit (Bio-Rad, USA). The proteins $(30 \mu \mathrm{g})$ were denatured by heating $\left(5 \mathrm{~min}, 100{ }^{\circ} \mathrm{C}\right)$ and electrophoretically separated in $12 \%$ SDS-PAGE under reduction conditions. The protein was then transferred onto a nitrocellulose membrane (Sigma, Shanghai, China). The membrane was blocked with $5 \%$ skimmed milk containing PBST (PBS containing 0.1\% Tween 20) for $1 \mathrm{~h}$ and incubated with the anti-gB monoclonal antibody BA4 $(10 \mu \mathrm{g} / \mathrm{mL})$ and anti-tubulin antibody $(10 \mu \mathrm{g} /$ $\mathrm{mL}$ ) as internal control for $2 \mathrm{~h}$ at room temperature. The membrane was washed three times with PBST and incubated with the appropriate HRP secondary antibody (SIGMA, Shanghai, China) for $60 \mathrm{~min}$ at $37^{\circ} \mathrm{C}$. After washing with PBST, the membrane was developed using Bio-Rad enhanced chemiluminescent substrate and photographed with an ultrasensitive chemiluminescence detector (Proteinsimple, USA).

\section{Statistical analyses}

The results represent the means \pm standard deviations (SD) of triplicate determinations. The significance of the variability between the trials was analyzed using GraphPad (version 5.0) software. Differences between samples were assessed by the Student's t-test, and $p$ values $<0.05$ were statistically significant. The experiment was performed at least three times independently with the similar results.

\section{Supplementary information}

Supplementary information accompanies this paper at https://doi.org/10. 1186/s12917-020-02595-x.

Additional file 1 Figure S1. The full-length blot images of Fig.2d in the manuscript.

\section{Abbreviations}

MD: Marek's disease; MDV: Marek's disease virus; ALV-J: Avian leukosis virus subgroup J; NDV: Newcastle disease virus; TCM: Traditional Chinese Medicine; NA: Neuraminidase; mAb: Monoclonal antibody; FBS: Foetal bovine serum; DMEM: Dulbecco's modified Eagle's medium; FITC: Fluorescein isothiocyanate

\section{Acknowledgements}

Not applicable.

\section{Authors' contributions}

$\mathrm{KQ}$ and FY designed the project. FY and CF carried out the experiments, analysed the data, and drafted the manuscript. KQ supervised all the experiments and participated in the data analysis. HS, YY and AQ discussed and prepared the final report. All of the authors have read and approved the final manuscript.

\section{Funding}

The research was supported by the Key Program of NSFC-Henan Joint Fund (U1604232), the National key research and development program (Grant No.2017YFD0500702), the National Natural Science Foundation of China (Grant No. 31772734, 31972717), NCFC-RCUK-BBSRC (Grant No. 31761133002), Biological Sciences Research Council (BBSRC) grant BB/R007896/1, the Priority Academic Program Development of Jiangsu Higher Education Institutions and the Jiangsu Co-innovation Centre for the Prevention and Control of Important Animal Infectious Diseases and Zoonoses. The funding group provided the financial support to cover the costs of the material used for research without intellectually contributing, analysis or interpreting.

\section{Availability of data and materials}

The datasets used and/or analysed during the current study are available from the corresponding author on reasonable request.

\section{Ethics approval and consent to participate}

All the animal experiments were performed according to the institutional animal care guidelines and approved by the Institutional Animal Care and Use Committee of Yangzhou University.

\section{Consent for publication}

Not applicable.

\section{Competing interests}

The authors declare that they have no competing interests.

\section{Author details}

${ }^{1}$ Ministry of Education Key Lab for Avian Preventive Medicine, Yangzhou University, No.48 East Wenhui Road, Yangzhou, Jiangsu 225009, P.R. China. ${ }^{2}$ Jiangsu Key Lab of Preventive Veterinary Medicine, Yangzhou University, No.48 East Wenhui Road, Yangzhou, Jiangsu 225009, P.R. China. ${ }^{3}$ The International Joint Laboratory for Cooperation in Agriculture and Agricultural 
Product Safety, Ministry of Education, Yangzhou University, Yangzhou 225009, P.R. China. ${ }^{4}$ The Pirbright Institute \& UK-China Centre of Excellence for Research on Avian Diseases, Pirbright, Surrey GU24 ONF, UK. Institute of Comparative Medicine, Yangzhou University, Yangzhou, Jiangsu 225009, P.R. China. ${ }^{6}$ Yangzhou, P. R. China.

Received: 1 June 2020 Accepted: 28 September 2020

Published online: 02 October 2020

\section{References}

1. Biggs PM, Nair V. The long view: 40 years of Marek's disease research and avian pathology. Avian Pathology. 2012;41(1):3-9.

2. Boodhoo N, Gurung A, Sharif S, Behboudi S. Marek's disease in chickens: a review with focus on immunology. Vet Res. 2016;47.

3. Sun GR, Zhang YP, Lv HC, Zhou LY, Cui HY, Gao YL, Qi XL, Wang YQ, Li K, Gao L, et al. A Chinese Variant Marek's Disease Virus Strain with Divergence between Virulence and Vaccine Resistance. Viruses. 2017;9:4.

4. Machida Y, Murata S, Matsuyama-Kato A, Isezaki M, Taneno A, Sakai E, Konnai S, Ohashi K. Isolation and purification of Gallid herpesvirus 2 strains currently distributed in Japan. J Vet Med Sci. 2017;79(1):115-22.

5. Zhuang X, Zou H, Shi H, Shao H, Ye J, Miao J, Wu G, Qin A. Outbreak of Marek's disease in a vaccinated broiler breeding flock during its peak egglaying period in China. BMC Vet Res. 2015;11:157

6. Gong Z, Zhang L, Wang J, Chen L, Shan H, Wang Z, Ma H. Isolation and analysis of a very virulent Marek's disease virus strain in China. Virol J. 2013; 10:155.

7. $\quad$ Ding Y, Dou J, Teng Z, Yu J, Wang T, Lu N, Wang H, Zhou C. Antiviral activity of baicalin against influenza a (H1N1/H3N2) virus in cell culture and in mice and its inhibition of neuraminidase. Arch Virol. 2014;159(12):326978 .

8. Lyu SY, Rhim JY, Park WB. Antiherpetic activities of flavonoids against herpes simplex virus type 1 (HSV-1) and type 2 (HSV-2) in vitro. Arch Pharm Res. 2005;28(11):1293-301.

9. Moghaddam E, Teoh BT, Sam SS, Lani R, Hassandarvish P, Chik Z, Yueh A, Abubakar S, Zandi K. Baicalin, a metabolite of baicalein with antiviral activity against dengue virus. Sci Rep. 2014;4:5452.

10. Nayak MK, Agrawal AS, Bose S, Naskar S, Bhowmick R, Chakrabarti S, Sarkar S, Chawla-Sarkar M. Antiviral activity of baicalin against influenza virus H1N1-pdm09 is due to modulation of NS1-mediated cellular innate immune responses. J Antimicrob Chemother. 2014;69(5):1298-310.

11. Qian K, Kong Z-R, Zhang J, Cheng X-W, Wu Z-Y, Gu C-X, Shao H-X, Qin A-J. Baicalin is an inhibitor of subgroup $J$ avian leukosis virus infection. Virus Res. 2018;248:63-70.

12. Ye C, Li S, Yao W, Xu L, Qiu Y, Liu Y, Wu Z, Hou Y. The anti-inflammatory effects of baicalin through suppression of NLRP3 inflammasome pathway in LPS-challenged piglet mononuclear phagocytes. Innate immunity. 2016; 22(3):196-204.

13. Lee W, Ku SK, Bae JS. Anti-inflammatory effects of Baicalin, Baicalein, and Wogonin in vitro and in vivo. Inflammation. 2015;38(1):110-25.

14. Hsiao WLW, Liu L. The role of traditional Chinese herbal medicines in Cancer therapy - from TCM theory to mechanistic insights. Planta Med. 2010;76(11):1118-31

15. Jia Y, Xu R, Hu Y, Zhu T, Ma T, Wu H, Hu L. Anti-NDV activity of baicalin from a traditional Chinese medicine in vitro. J Vet Med Sci. 2016;78(5):81924.

16. Mounce BC, Cesaro T, Carrau L, Vallet T, Vignuzzi M. Curcumin inhibits Zika and chikungunya virus infection by inhibiting cell binding. Antivir Res. 2017; 142:148-57.

17. Chen Y, Zeng L, Yang J, Wang Y, Yao F, Wu Y, Wang D, Hu Y, Liu J. AntiDHAV-1 reproduction and immuno-regulatory effects of a flavonoid prescription on duck virus hepatitis. Pharm Biol. 2017;55(1):1545-52.

18. Sun Y, Niu L, Song M, Zhao X, Sun N, He J, Wu C, Jiang J, Bai Y, Guo J, et al. Screening compounds of Chinese medicinal herbs anti-Marek's disease virus. Pharm Biol. 2014;52(7):841-7.

19. Hu X, Xu W, Qin A, Wu G, Qian K, Shao H, Ye J. Marek's disease virus may interfere with T cell immunity by TLR3 signals. Vet Res Commun. 2014;38(2): 149-56.

20. Pang P, Zheng K, Wu S, Xu H, Deng L, Shi Y, Chen X. Baicalin Downregulates RLRs signaling pathway to control influenza a virus infection and improve the prognosis. Evid Based Complement Alternat Med. 2018.
21. Qian K, Gao AJ, Zhu MY, Shao HX, Jin WJ, Ye JQ, Qin AJ. Genistein inhibits the replication of avian leucosis virus subgroup J in DF-1 cells. Virus Res. 2014;192:114-20.

\section{Publisher's Note}

Springer Nature remains neutral with regard to jurisdictional claims in published maps and institutional affiliations.
Ready to submit your research? Choose BMC and benefit from:

- fast, convenient online submission

- thorough peer review by experienced researchers in your field

- rapid publication on acceptance

- support for research data, including large and complex data types

- gold Open Access which fosters wider collaboration and increased citations

- maximum visibility for your research: over $100 \mathrm{M}$ website views per year

At BMC, research is always in progress.

Learn more biomedcentral.com/submissions 